https://doi.org/10.30910/turkjans.709303

\begin{tabular}{c}
\hline TÜRK \\
TARIM ve DOĞA BILIMLERI \\
DERGISI \\
\hline \hline
\end{tabular}

\section{Araştırma Makalesi \\ Tarsus Bağ Alanlarında Neofusicoccum parvum'un Yaygınlığı ve Bazı Sofralık Üzüm Çeşitlerinin Patojene Duyarlılıkları}

\author{
Dilara GÜLER ${ }^{1}$ Davut Soner AKGÜL ${ }^{1}$ \\ ${ }^{1}$ Çukurova Üniversitesi, Ziraat Fakültesi, Bitki Koruma Bölümü, 01330, Balcalı, Adana \\ Sorumlu yazar: sakgul@cu.edu.tr
}

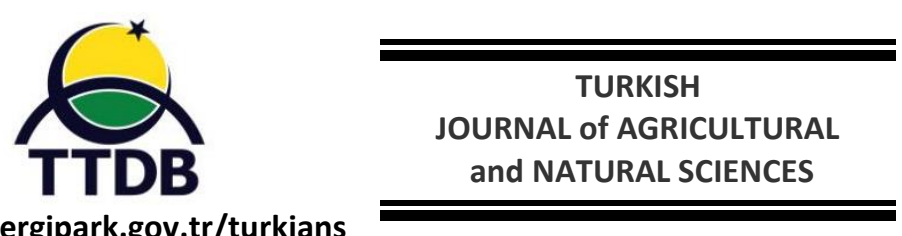

www.dergipark.gov.tr/turkjans and NATURAL SCIENCES

Geliş Tarihi: 25.03.2020 Düzeltme Geliş Tarihi: 17.05.2020 Kabul Tarihi: 29.05.2020

$\overline{\text { Öz }}$

Bu çalışmada asmada Botryosphaeria Geriye Ölüm Hastalığı etmenlerinden Neofusicoccum parvum türünün Tarsus bağlarındaki yaygınlığı ve bölgede yetiştirilen bazı sofralık üzüm çeşitlerinin patojene duyarlılıklarının araştııılması amaçlanmıştır. Ağustos 2018'de Tarsus'a bağı 12 farklı köyde 50 bağ incelenmiş, simptomatik asmaların varlığına göre hastalık yaygınlığı hesaplanmış ve fungal izolatları elde etmek için hastalık belirtisi gösteren asmalardan odunsu doku örnekleri alınmıştır. Laboratuvarda standart mikolojik izolasyon yöntemleri takip edilmiş, Botryosphaeriaceae türlerine benzeyen koloniler saflaştırılmıştır. İzolatlar moleküler yöntemlerle tanılanmış ve Neofusicoccum parvum izolatları ile patojenisite çalışmaları yürütülmüştür. En virülent iki izolat çeşit duyarlılığı çalışmaları için seçilmiş, bunlar bölgede yaygın yetiştirilen 11 asma çeşidine inokule edilmiş ve odunsu dokularda oluşan lezyonlara göre çeşitlerin duyarlıık seviyeleri belirlenmiştir. Sonuçlara göre, hastalığın Tarsus'taki yaygınlığının \%14 olduğu saptanmış ve laboratuvar çalışmalarında 21 Botryosphaeriaceae izolatı elde edilmiştir. Moleküler tanı çalışmalarıyla bu izolatlardan \%61.9'unun Diplodia seriata, \%23.8'inin Lasiodiplodia pseudotheobromae, \%14.3'ünün Neofusicoccum parvum ve \%4.8'sinin Lasiodiplodia theobromae olduğu bulunmuştur. Patojenisite denemesi sonunda, en virülent $N$. parvum izolatları (49 ve 103) asma bitkilerinde 12.5-20.5 mm arasında değişen uzunluklarda odun doku lezyonlarına neden olmuşlardır. Çeşitlerin bu izolatlara karşı duyarlılığı birbirinden farklılık göstermiş, bunların duyarlılık sıralamaları birebir aynı olmamıştır. N. parvum izolatları inokule edildiğinde en tolerant üzüm çeşidi 12.5 ve 13.1 mm'lik lezyon uzunluklarıyla Cardinal çeşidi olmuştur. 49 nolu izolatın oluşturduğu lezyonlar çeşitler üzerinde istatistiksel olarak küçük farklar meydana getirmiş ancak 103 nolu izolatın oluşturduğu istatistiksel gruplar geniş aralıkta olmuştur.

Anahtar kelimeler: Asma, Botryosphaeriaceae, cardinal, Neofusicoccum

Prevalence of Neofusicoccum parvum in the Tarsus Vineyards and Susceptibility of Some Table Grapes to the Pathogen

\title{
Abstract
}

The aims of the study were to reveal the prevalence of Neofusicoccum parvum, one of the species causing Botryosphaeria Dieback Disease, in Tarsus vineyards and to determine susceptibility of commonly grown table grape cultivars to the pathogen. Fifty vineyards were examined in 12 villages of Tarsus, the disease prevalence was calculated according to presence of the symptomatic vines and symptomatic wood samples were taken to obtain fungal isolates. Standard mycological isolation procedures were followed in the laboratory and the colonies resembling Botryosphaeriaceae species were sub-cultured. The isolates were identified by molecular tools and pathogenicity studies were conducted with Neofusicoccum parvum isolates. For cultivar susceptibility studies, the most virulent two N. parvum isolates were selected and inoculated to 11 commonly grown (in the region) grape cultivars and susceptibility levels of the cultivars were determined by lesion occurrence on woody tissues. According to results, disease prevalence was determined to be $14 \%$ in the Region and 21 Botryosphaeriaceous isolates were obtained from the isolations. It was found in the molecular studies that $61.9 \%$ of the isolates were Diplodia seriata, $23.8 \%$ were Lasiodiplodia pseudotheobromae, $14.3 \%$ 
were Neofusicoccum parvum and $4.8 \%$ were Lasiodiplodia theobromae. The most virulent $N$. parvum isolates isolates (49 and 103) caused wood lesions that their lengths changing 12.5-20.5 mm grapevine plants. The sensitivity of the cultivars to these isolates differed from each other, their sensitivity levels were not the same in the rankings. The most tolerant grape cultivar was Cardinal (with 12.5 and 13.1 $\mathrm{mm}$ lesion lengths) when $N$. parvum isolates inoculated. The lesions formed by the isolate 49 had little differences on the cultivars statistically, but the statistical groups formed by the isolate 103 were wide in range.

Key words: Grapevine, Botryosphaeriaceae, cardinal, Neofusicoccum parvum

\section{Giriş}

Bağlarda Botryosphaeriaceae familyasına bağlı fungus türlerinin neden olduğu "Botryosphaeria Geriye Ölüm Hastalığı" son yıllarda dünyada ve ülkemizdeki bağ alanlarında oldukça sık görülmeye başlayan tehlikeli bir hastalıktır. Omcalarda lokal kurumalar, odun dokulardaki "V" şeklinde nekrotik lezyonlar, genç ya da yaşlı asmalarda uyanma bozuklukları ve fidanlıklarda görülen kurumalar hastalığın başlıca belirtileri arasındadır. Yapılan bir araştırmaya göre Kuzey Amerika'daki bağ alanlarında Botryosphaeriaceae ve Diatrypaceae familyasında bulunan patojenik türlerin, yıllık olarak yaklaşık 260 milyon dolarlık ekonomik kayba neden olduğu hesaplanmıştır (Siebert, 2001). Botryosphaeriaceae familyası içerisinde pek çok önemli cins bulunmakta olup, asmada şimdiye kadar bu cinsler içerisinde gruplandırılan 24 farklı türün bu hastalığa neden olduğu bildirilmiştir (Úrbez-Torres ve ark., 2015). Botryosphaeria, Diplodia, Dothiorella, Lasiodiplodia, Neofusicoccum, Neoscytalidium, Spencermartinsia ve Sphaeropsis cinsi içerisinde bulunan türler, virülenslikleri birbirlerinden farklı olmakla birlikte, asmalarda kaydedilen patojenik türlerdir. Yapılan birçok çalışmanın ortak sonucunda Lasiodiplodia ve Neofusicoccum türlerinin en saldırgan, Botryosphaeria dothidea ve Diplodia türlerinin orta derecede saldırgan ve Dothiorella ve Spencermartinsia viticola'nın ise düşük derecede saldırgan oldukları anlaşılmıştır (Luque ve ark., 2009; Úrbez-Torres ve Gubler 2009; Úrbez-Torres ve Gubler 2011). Bunlar içerisinde Neofusicoccum parvum (Pennycook \& Samuels) Crous, Slippers \& A.J.L. Phillips, bağcılığın yapıldığı alanlarda virülensliğinin yüksek ve yaygınlığının fazla olması nedeniyle ayrı bir öneme sahiptir. Bu patojen daha çok asmadaki budama yaralarından giriş yaparak iç dokulara doğru ilerler, salgıladığı yıkıcı toksinlerle doku ve organların kuruyarak ölmesine neden olur. Bağ alanlarında $N$. parvum türünün baskın durumda olması, o bölgedeki asmaların kısa sürede ölmesi anlamına gelebilir ya da asma fidan üretimi için 0 bölgeden alınan dormant kalemlerle, patojenin diğer bölgelere latent olarak yayılması söz konusu olabilir (Slippers ve Wingfield 2007). Tarsus Bölgesi turfanda sofralık üzüm üretimi için önemli bir bölge olup, asma fidanı üretimi için farklı çeşitlerin kalemleri bu bölgeden yurdun diğer bölgelerine gönderilmektedir. Patojenin latent halde taşınması göz önünde tutularak bu bölgede $N$. parvum türünün yaygınlığının araştırılması, ülkemizdeki asma fidanı üretiminde karşılaşılacak riskleri azaltmaya katkı sağlayacaktır. Bulunan yaygınlık sonuçlarına göre asma fidanı üreten işletmelerin, bu durumu dikkate alarak henüz fidan üretim aşamasında $N$. parvum'un latent infeksiyonlarını azaltıcı uygulamaları benimsemesi sağlanabilecektir. Ege Bölgesi sultani çekirdeksiz bağ alanlarında yürütülen bir çalışmada, fungal gövde hastalıklarına neden olan patojenlerden Botryosphaeriaceae Geriye Ölüm Hastalığı'nın yaygın olduğu saptanmış ve Diplodia seriata'dan sonra en çok izole edilen türün N. parvum olduğu bulunmuştur (Akgül ve ark., 2015). Polat ve ark., (2016) tarafından Yalova ili kivi bahçelerinde kuruma belirtisi gösteren ağaçlardan $N$. parvum'u izole ederek Türkiye'deki varlığını rapor etmişler ve bu etmenin patojenisitesini doğrulamışlardır. Kayım ve ark., (2015) Adana ve Hatay ili badem yetiştirilen alanlarda kuruma ve sakızlanma belirtisi gösteren ağaçlardan $N$. parvum ve $D$. seriata türlerini izole ederek Türkiye'de bu hastalığın var olduğunu bildirmişler ve izolatların patojenisitesini doğrulamışlardır. Tarsus Bölgesi bağlarında bu patojenin yaygınlığıyla ilgili bir çalışmaya henüz rastlanmamıştır.

Asmalarda Botryosphaeria Geriye Ölüm Hastalığı'nın mücadelesinde etkili yöntemler arasında; hastalığın yayılmasına engel olmak ve hastalığa duyarlılığı az olan çeşitleri tercih etmek yer alır. Hastalığa duyarlılığı düşük olan bitkilerde patojenin ilerleyişi yavaş ve duyarlı 
olan çeşitlerle kıyaslandığında omcanın ömrü daha uzun olmaktadır. Bu nedenle hastalığa tolerant çeşitlerin saptanması hastalıkla mücadeleye bir miktar katkı sağlayacaktır. Travadon ve ark., (2013) tarafından yürütülen bir çalışmada $N$. parvum, Lasiodiplodia theobromae, Phaeomoniella chlamydospora ve Togninia minima türlerine karşı 7 farklı üzüm çeşidinin (Cabernet Franc, Cabernet Sauvignon, Chardonnay, Merlot, Riesling, Petite Syrah, Thompson Seedless) duyarlılıkları incelenmiştir. Bu çeşitlerden N. parvum'a karşı duyarlılığı en az olan çeşidin Concord olduğu bildirilmiştir. Billones-Baaijens ve ark., (2014), Yeni Zelanda'nın farklı bölgelerinde yaygın yetiştirilen 6 anaç (101-104 Millardet, 5C Teleki, 3309 Courdec, Riparia Gloire, Schwarzmann, SO4) ve 6 üzüm çeşidi (Sauvignon Blanc, Chardonnay, Riesling, Pinot Noir, Merlot, Cabernet Sauvignon) olmak üzere toplam 12 çeşidin Botryosphaeriaceae türlerine ( $N$. parvum, $N$. luteum ve $N$. australe) olan duyarlııklarını araştırmışlardır. Çalışma sonunda bu patojenlere en tolerant üzüm çeşidinin Chardonnay, en duyarlısının ise Merlot ve Pinot Noir çeşitleri olduğu bulunmuş diğer taraftan 101-104 Millardet anacının en tolerant Teleki-5C'nin ise en duyarlı olduğu tespit edilmiştir. Ülkemizde yerli veya yabancı menşeli çok sayıda standart üzüm çeşidi mevcut olup, bu çeşitlerin N. parvum'a duyarlılık seviyelerinin belirlendiği bir çalışma henüz yapılmamış ve böyle bir çalışmaya gerek duyulmuştur.

Bu çalışmada; N. parvum'un Tarsus ilçesi bağ alanlarında yaygınlığını belirlemek ve bölgeden izole edilen en virülent izolata karşı yaygın üzüm çeşitlerinin duyarlılık seviyelerini ortaya koymak amaçlanmıştır.

\section{Materyal ve Yöntem \\ Örnek Toplama ve Hastalık Yaygınlığını Belirlemeye Yönelik Çalışmalar}

Mersin ili Tarsus Bölgesi'nde yaygın olarak yetiştirilen Alphonse Lavallée, Black Magic, Cardinal, Ergin Çekirdeksiz, Göğ Üzüm, Michele Palieri, Perlette, Prima, Tarsus Beyazı, Victoria ve Yalova İncisi adlı sofralık çeşitler çalışmanın bitkisel materyallerini oluşturmuşlardır. Tarsus'ta bağcılık yapılan Cinköy, Çakırlı, Çiriştepe, Dedeler, Ibrişim, Karadiken, Sarıveli, Sucular, Takbaş, Taşçılı, Tepeköy, Ulaş köylerindeki 50 bağda incelemeler yapılmıştır (Ağustos 2018). Köylerin sınırları içinde verim çağındaki bir bağa girilerek her iki kenardan ve ortadan dörder sırada (toplam 12 sıra), Botryosphaeria Geriye Ölüm Hastalığı'nın belirtileri incelenmiş, hastalığın o bağda var olup olmadığı saptanmıştır. Buna göre inceleme yapılan toplam bağ sayısına göre hastalık yaygınlığı hesaplanmıştır. Hastalığın görüldüğü asmaların en az 2 yıllık dallarından alınan örnekler laboratuvara getirilerek yıkanmış, dokuların yüzeyi standart mikolojik izolasyon yöntemlerine göre dezenfekte edilmiştir. Bu dokular 3-5 $\mathrm{mm}$ büyüklüğünde kesilerek, streptomycin içeren (150 $\left.\mathrm{mg} \cdot \mathrm{L}^{-1}\right)$ patates dekstroz agar (PDA: Merck) besi yerine kültüre alınmışlardır. Steril plastik Petri kaplarındaki dokular $25^{\circ} \mathrm{C}^{\prime}$ de 5 gün inkübe edildikten sonra koloni özellikleri ve mikroskobik incelemelere göre (Crous ve ark., 2006) saflaştırılmışlardır.

\section{Neofusicoccum parvum'un Moleküler ve Morfolojik Tanısı}

Botryosphaeriaceae türlerine benzerlik gösteren saf kolonilerden DNA ekstraksiyonu yapılmıştır (Ma ve Dai 2009). Öncelikle PDA yüzeyinden steril bisturi ile miselyum alınarak ezme poşetlerine koyulmuş ve mekanik olarak ezilmiştir. Bu poşetlere $650 \mu \mathrm{l} \% 2^{\prime}$ lik CTAB (Cetyl Trimethyl Ammonium Bromide) buffer eklenerek karıştırılmış ve tüplere alındıktan sonra içerisinde $2 \mu \mathrm{l}$ mercaptoethanol koyulmuştur. Bu karışım vortex ile homojenize edilip $65^{\circ} \mathrm{C}^{\prime}$ deki kuru blok ısıtıcıda 1 saat ısıtılmıştır. Ardından $650 \mu \mathrm{l}$ chloroform isoamylalkol (24:1) eklenerek vortexlenmiş ve 14000 rpm'de 10 dk santrifüj edilmiştir. Üstteki sıvı alınarak yeni tüplere koyulmuş ve eşit hacimde yeniden chloroform isoamylalkol ile muamele edilmiştir. İkinci kez santrifüjün ardından (14000 rpm, $10 \mathrm{dk}$ ) üst sıvı alınarak başka bir tüpe koyulmuş ve isopropanol ile 30 dakika süreyle $-20^{\circ} \mathrm{C}$ 'de çöktürülmüştür. Daha sonra 14000 rpm'de 15 dk'lık son santrifüjün ardından sıvı kısım atılarak DNA pelleti \%70'lik alkolle yıkanmış ve fazla sıvı kurutulduktan sonra TE buffer ile süspanse edilmiştir.

PCR işlemi ile genomik DNA'daki ITS bölgeleri, ITS4-ITS5 primerleri ile çoğaltılmıştır (White ve ark. 1990). PCR karışımı her bir tüp için şu şekilde hazırlanmıştır; $2.5 \mu \mathrm{l}$ 10X Buffer (Thermo Scientific ${ }^{\circledR}$ ), $1 \mu \mathrm{l}$ dNTPs, $0.5 \mu$ l primer (ITS4 ve ITS5), $0.125 \mu$ l Taq polimeraz (Thermo Scientific $\left.{ }^{\circledR}\right)$ ve $2 \mu$ l genomik DNA. Tüplerdeki içerik iyice karıştırıldıktan sonra thermocycler cihazına yerleştirilmiş ve şu programa göre çalıştırılmıştır; $95^{\circ} \mathrm{C}^{\prime} \mathrm{de} 3 \mathrm{dk}$ (ilk denatürasyon), 
$95^{\circ} \mathrm{C}^{\prime}$ de $1 \mathrm{dk}, 52^{\circ} \mathrm{C}^{\prime}$ de $1 \mathrm{dk}$ ve $72^{\circ} \mathrm{C}^{\prime}$ de $1 \mathrm{dk}$ (35 döngü) ve $72^{\circ} \mathrm{C}^{\prime}$ de10 dk (son döngü). Daha sonra PCR ürünleri \%1.5'lik agaroz jelde 2 saat süreyle yürütülmüş $(55 \mathrm{~V}, 400 \mathrm{~mA})$ ve oluşan bantlara göre çoğaltılan bölgenin DNA'sı görüntülenmiştir. PCR ürünleri Sanger yöntemine göre dizilendikten sonra nükleotid dizileri NCBI-BLASTn yazılımı ile NCBI gen bankasındaki dizilerle karşılaştırılmış ve izolatların hangi türe ait oldukları en az \%99'luk benzerlikle doğrulanmıştır. Türlerin nükleotid dizileri NCBI gen bankasına kaydedilerek kayıt numarası alınmıştır.

Moleküler tanı ile $N$. parvum olduğu belirlenen izolatlar, aynı zamanda klasik tanı ile doğrulanmıştır. Bunun için PDA'da gelişen bir koloniden $5 \mathrm{~mm}$ çaplı miseliyal disk alınıp dormant haldeki asma kalemlerine (Prima çeşidi) inokule edilmiştir (Úrbez-Torres ve ark., 2006). Bu kalemlerin dip kısmı suda kalacak şekilde plastik kaplara koyulmuş ve $25^{\circ} \mathrm{C}$ 'de $\% 90$ nispi nemde 18 gün süreyle inkübe edilmiştir. Kabuklar üzerinde oluşan piknidyumlardaki pikniosporlar mikroskopta incelenerek fotoğraflanmış, koloni morfolojisi ve spor şekillerine göre klasik tanı tamamlanmıştır.

\section{Patojenisite Testi}

Tanısı yapılan $N$. parvum izolatları patojenisite testine alınmıştır. Daha önce Tarsus bağlarından izole edilerek patojenisitesi doğrulanmış başka bir izolat, mukayese amacıyla bu teste dahil edilmiştir. Yaklaşık 30 $\mathrm{cm}$ uzunluğundaki dormant asma kalemlerinin (Prima çeşidi) uç kısmına miseliyal agar diskleri yerleştirilip üzeri parafilm ile sarılmıştır. Bu kalemler strafor köpüklere saplanarak içerisinde çeşme suyu bulunan küvetlerde yüzdürülmüş, bu küvetler $25^{\circ} \mathrm{C}$ sıcaklık, 12 saat aydınlık/karanlık ve $\% 90$ nispi nemde 45 gün süreyle tutulmuştur (Ayres ve ark., 2011). Küvetlerdeki sular her gün yenilenmiştir. Bu süre sonunda kalemler bulundukları yerden çıkarılıp uç kısımları bıçakla boydan ikiye ayrılarak iç kısımdaki lezyonların uzunlukları ölçülmüştür. Denemede her bir izolat için 5 tekerrür (her tekerrürde 2 kalem) tertip edilmiş ve toplam 10 kalem kullanılmıştır. Kontroldeki kalemlere steril agar inokule edilmiştir. Lezyon uzunluklarının ortalaması alınarak en uzun lezyon oluşturan iki izolat çeşit duyarlılığı çalışmaları için seçilmiştir.

\section{Çeşit Duyarlılığı Çalışmaları}

Çalışmanın bu bölümünde Tarsus ilçesinde yaygın yetiştirilen Alphonse Lavallée, Black Magic, Cardinal, Ergin Çekirdeksizi, Göğ Üzüm, Michele Palieri, Perlette, Prima, Tarsus Beyazı, Yalova İncisi ve Victoria çeşitlerinin, $N$. parvum'a olan duyarlılıkları incelenmiştir. Bu çeşitlerin dormant kalemleri, ilçedeki bağ alanlarından kesilerek 1 gece çeşme suyunda bekletilmiştir. Ertesi gün $N$. parvum'un en virülent iki izolatından miseliyal agar diskleri alınarak mantar delici ile kalemlerin kabuk dokusu altına inokule edilmiş ve inokulasyon noktaları parafilmle sarılmıştır. Kontrol uygulamasında kalemlere sadece steril agar inokule edilmiştir. Asma kalemleri, içerisinde yetiştirme harcı (her birinden eşit oranda; torf, perlit, talaş, kum, toprak ve çiftlik gübresi) bulunan plastik torbalara ( $1 \mathrm{~L}$ ) dikilmiş ve yetiştirme odası koşullarında $\left(27^{\circ} \mathrm{C}\right.$ sıcaklık, \%85 nispi nem, 12 saat aydınlık/karanlık) 80 gün süreyle büyütülmüşlerdir. Kök ve sürgün oluşturan bitkiler daha sonra torbalardan sökülerek inokulasyon bölgesindeki kabuk doku bıçakla sıyrılmış ve odun dokudaki lezyonların uzunlukları ölçülmüştür. Deneme tesadüf parselleri deneme desenine göre kurulmuş, her bir çeşit için 20 bitkiden ölçüm yapılmıştır (4 tekerrür, her bir tekerrürde 5 asma). Her tekerrürde kaydedilen lezyon uzunluklarına varyans analizi uygulanmış, ortalamalar arasındaki farklar LSD testine göre \%5'lik hata payıyla değerlendirilmiştir (Gomez ve Gomez 1984). Karşılaştırma amacıyla her bir çeşit için kontrol bitkileri de büyütülmüş ancak bunlardaki lezyon uzunlukları varyans analizine alınmamıştır.

\section{Araştırma Bulguları ve Tartışma \\ Hastalığın Yaygınlığı ve Bölgede Saptanan Botryosphaeriaceae Türleri}

Tarsus'a bağlı köylerde, yaşları 5-10 arasında değişen 50 farklı bağın sadece 7 'sinde bariz hastalık belirtileri görülmüş ve bölgedeki hastalık yaygınlığı \%14 olarak hesaplanmıştır. Ege Bölgesi Sultani Çekirdeksiz bağ alanlarında yürütülen bir çalışmada, en az 10 yaşındaki bağların \%80'inden fazlasında, asma gövde hastalıklarından en az birinin görüldüğü bildirilmiştir. Botryosphaeriaceae türleri ve Diaporthe ampelina en çok izole edilen patojenler olup bunların izole edilme oranları \%1.3 ile \%22.6 arasında değişmiş, Diaporthe ampelina'nın daha sık izole edilmesine vurgu yapılmıştır. Ancak o bölgedeki yüksek oranın 
tamamı Botryospaheriaceae türlerinden ibaret değildir (Akgül ve ark., 2015). Tarsus'taki \%14'lük hastalık yaygınlığının Ege Bölgesi'ne göre daha düşük olması, incelenen bağların yaşlarıyla ilişkili olmasındandır. Botryosphaeria Geriye Ölüm Hastalığı henüz 2-3 yıllık bağlarda görülebilse de, daha çok yaşlı bağlarda sıkça karşılaşılan bir hastalıktır. Bu bölgelerden başka hastalık yaygınlığını ortaya koyan ulusal bir çalışmaya rastlanmamıştır.

İzolasyon çalışmalarıyla bölgeden toplam 21 Botryosphaeriaceae izolatı elde edilmiş olup moleküler tanı sonucunda bunlardan 13'ünün (\%61.9) Diplodia seriata, dördünün (\%23.8) Lasiodiplodia pseudotheobromae, birinin (\%4.8) Lasiodiplodia theobromae ve üçünün (\%14.3) ise Neofusicoccum parvum türü oldukları bulunmuştur. Bu türlerin ITS nükleotid dizileri NCBI gen bankasına kaydedilerek kayıt numarası alınmış ve tür tanısı doğrulanmıştır (Çizelge 1). Buna göre Diplodia seriata'nın Tarsus Bölgesi bağ alanlarında diğerlerine göre yaygın bir tür olduğu söylenebilir. Bu tür daha önce yapılmış bazı araştırmaların sonuçlarına göre orta derecede saldırgan olarak gruplandırılmıştır (Úrbez-Torres ve Gubler 2009). Bölgeden elde edilen izolatların yaklaşık \%38'i ise Lasiodiplodia theobromae, $L$. pseudotheobromae ve $N$. parvum türlerinden oluşmaktadır. D. seriata'ya göre daha saldırgan olan N. parvum'un \%14.3 gibi düşük bir orana sahip olması, omcaların sağlığı açısından pozitif olarak görülmektedir. Klasik tanı için inokule edilen dormant kalemlerden 18-20 gün sonra piknidyumlar meydana gelmiş ve şeffaf, uzunoval pikniosporların görüntüsüne göre Neofusicoccum parvum'un tanısı doğrulanmıştır (Şekil 1).

Çizelge 1. Tarsus bağlarından izole edilen Botryosphaeriaeceae türleri ve NCBI gen bank kayıt numaraları

\begin{tabular}{|c|c|c|}
\hline İzolat No & $\begin{array}{l}\text { Moleküler Tanısı } \\
\text { Yapılan Türler }\end{array}$ & $\begin{array}{l}\text { NCBI Gen Bankası } \\
\text { Kayıt Numaraları }\end{array}$ \\
\hline Trs47 & Diplodia seriata & MN887195 \\
\hline Trs48 & Diplodia seriata & MN887196 \\
\hline $\operatorname{Trs} 50$ & Diplodia seriata & MN887198 \\
\hline $\operatorname{Trs} 54$ & Diplodia seriata & MN887199 \\
\hline Trs60 & Diplodia seriata & MN887201 \\
\hline Trs61 & Diplodia seriata & MN887202 \\
\hline Trs71 & Diplodia seriata & MN887207 \\
\hline Trs74 & Diplodia seriata & MN887208 \\
\hline Trs76 & Diplodia seriata & MN887209 \\
\hline Trs77 & Diplodia seriata & MN887210 \\
\hline Trs78 & Diplodia seriata & MN887211 \\
\hline Trs80 & Diplodia seriata & MN887213 \\
\hline Trs82 & Diplodia seriata & MN887214 \\
\hline $\operatorname{Trs} 58$ & Lasiodiplodia pseudotheobromae & MN887200 \\
\hline Trs68 & Lasiodiplodia pseudotheobromae & MN887204 \\
\hline Trs70 & Lasiodiplodia pseudotheobromae & MN887206 \\
\hline Trs79 & Lasiodiplodia pseudotheobromae & MN887212 \\
\hline Trs45 & Lasiodiplodia theobromae & MN887194 \\
\hline Trs49 & Neofusicoccum parvum & MN887197 \\
\hline Trs67 & Neofusicoccum parvum & MN887203 \\
\hline Trs69 & Neofusicoccum parvum & MN887205 \\
\hline
\end{tabular}



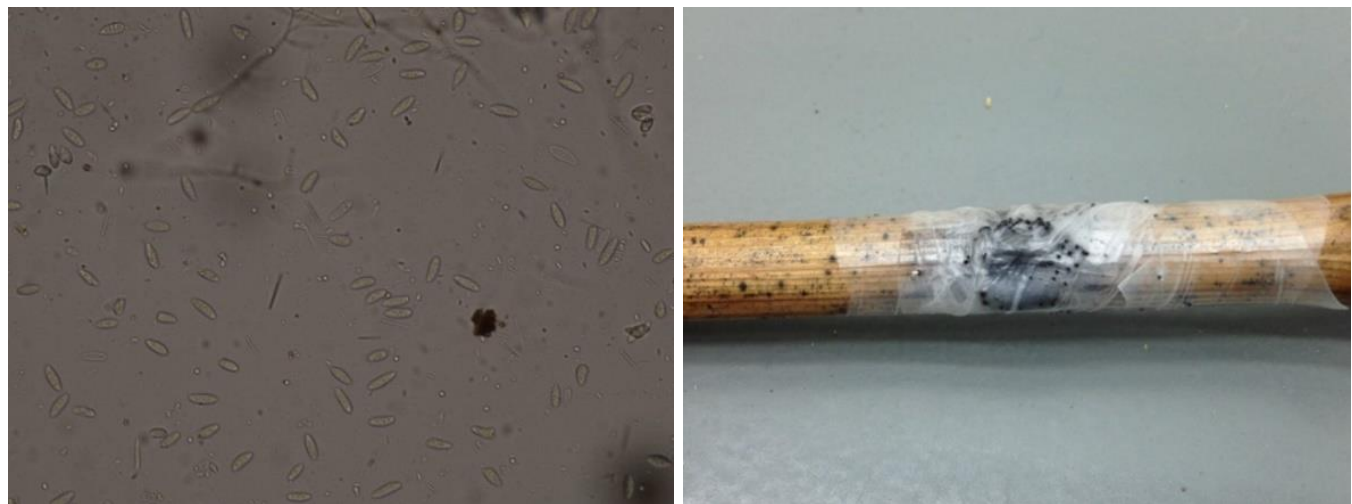

Şekil 1. Neofusicoccum parvum'un pikniosporları (sol) ve piknidyumları (sağ).

\section{Patojenisite Testi Sonuçları}

Çalışma kapsamında izole edilen 3 izolat (Trs49, Trs69 ve Trs84) ve patojenisitesi daha önce doğrulanmış başka bir Tarsus izolatı (Trs104) 45 günde, Prima asma kalemlerinde uzunlukları 9 ila $47.4 \mathrm{~mm}$ arasında değişen lezyonlar meydana getirmiştir (Şekil 2). Bunlar içerisinde en uzun lezyon oluşturan Trs49, en kısa lezyon oluşturan izolat ise Trs84 nolu izolat olmuştur. Çeşit duyarlılığı çalışmasına Trs49 ve Trs103 numaralı izolatlar seçilmiştir.

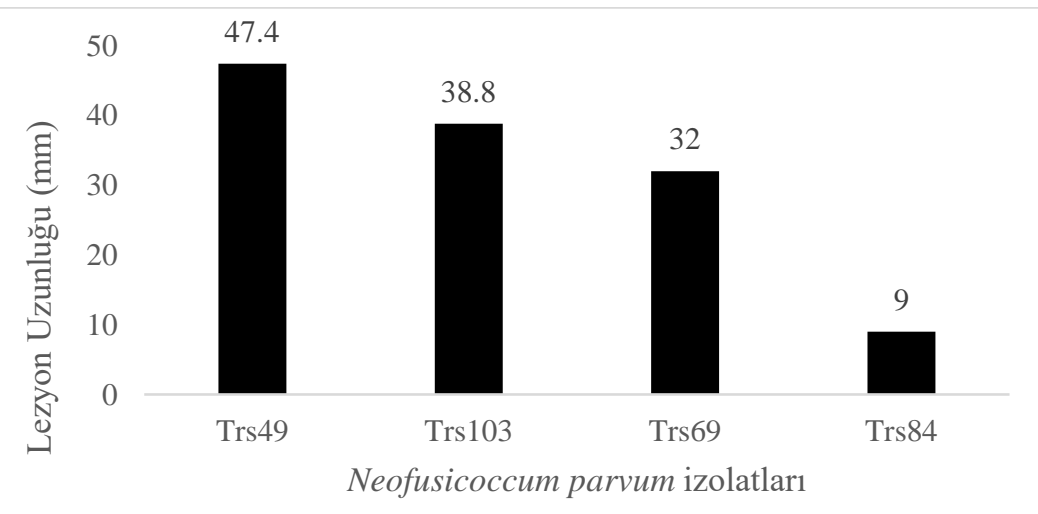

Şekil 2. Patojenisite testinde N. parvum izolatlarının, dormant Prima çeşidi asma kalemlerinde oluşturdukları lezyon uzunlukları $(\mathrm{mm})$.

\section{Çeşitlerin N. parvum izolatlarına Duyarlılıkları}

Çalışmaya dahil edilen iki N. parvum izolatı (Trs49 ve Trs103) farklı asma çeşitlerinde, uzunlukları 12.5 - $20.5 \mathrm{~mm}$ arasında değişen lezyonlar meydana getirmiştir. Her iki izolata karşı en az duyarlı olan çeşit Cardinal olmuştur. Trs49 nolu izolatın en az duyarlı çeşit ile (Cardinal) en duyarlı çeşitte (Tarsus Beyazı) meydana getirdiği lezyon uzunlukları farkı sadece $6.3 \mathrm{~mm}$ 'dir. Tekerrürlerdeki varyansın az olması ve rakamların birbirine yakınlığı ile istatistiksel gruplar da birbirine yakın olmuştur. Cardinal ve Tarsus Beyazı arasındaki istatistiksel farklar haricinde diğer çeşitlerin duyarlılıklarının birbirine çok yakın oldukları söylenebilir. Diğer yandan Trs103 nolu izolata karşı en az duyarlı çeşit (Cardinal) ile en duyarlı çeşidin (Perlette) meydana getirdikleri lezyonların farkı $7.4 \mathrm{~mm}$ olarak bulunmuş ve dolayısıyla ortalamalar arasındaki istatistiksel grupların çeşitliliği de artmıştır. Çeşitlerde oluşan ortalama lezyon uzunlukları küçükten büyüğe doğru sıralandıklarında, her iki izolatta farklı sıralama görülmüş ve birbiriyle paralel olmamıştır. Ancak her iki izolata karşı sıralamadaki ilk beş içerisinde yer alan ortak çeşitler; Cardinal, Ergin Çekirdeksizi ve Black Magic, son beş içerisinde ise Alphonse Lavallée, Tarsus Beyazı, Victoria ve Yalova İncisi yer almıştır (Çizelge 2). 
Çizelge 2. N. parvum izolatlarının farklı asma çeşitlerinde oluşturdukları lezyon uzunlukları

\begin{tabular}{|c|c|c|c|}
\hline \multicolumn{2}{|c|}{ Trs49 } & \multicolumn{2}{|c|}{ Trs103 } \\
\hline Çeşitler & Lezyon Uzunluğu (mm) & Çeşitler & Lezyon Uzunluğu (mm) \\
\hline Cardinal & $12.5 \pm 0.6 a^{*}$ & Cardinal & $13.1 \pm 0.6 a^{*}$ \\
\hline Göğ Üzüm & $15.3 \pm 0.6 \mathrm{ab}$ & Ergin Çekirdeksizi & $13.8 \pm 0.6 a b$ \\
\hline Perlette & $15.5 \pm 0.6 a b$ & Black Magic & $14.5 \pm 0.7 \mathrm{abc}$ \\
\hline Ergin Çekirdeksizi & $17.0 \pm 0.7 \mathrm{bc}$ & Michele Palieri & $15.5 \pm 0.9 \mathrm{abcd}$ \\
\hline Black Magic & $17.1 \pm 0.9 \mathrm{bc}$ & Prima & $16.2 \pm 0.6$ bcde \\
\hline Michele Palieri & $17.3 \pm 0.6 b c$ & Göğ Üzüm & $16.3 \pm 0.6$ bcde \\
\hline Prima & $17.8 \pm 0.8 b c$ & Tarsus Beyazı & $17.2 \pm 0.7 \mathrm{cde}$ \\
\hline Victoria & $17.9 \pm 0.9 \mathrm{bc}$ & Yalova İncisi & $17.9 \pm 0.7 \mathrm{def}$ \\
\hline Yalova İncisi & $18.2 \pm 0.5 b c$ & Victoria & $19.1 \pm 0.7$ ef \\
\hline Alphonse Lavallée & $18.3 \pm 0.6 \mathrm{bc}$ & Alphonse Lavallée & $20.3 \pm 0.7 f$ \\
\hline Tarsus Beyazı & $18.8 \pm 0.9 c$ & Perlette & $20.5 \pm 0.6 f$ \\
\hline
\end{tabular}

*Sütunlar içerisinde farklı harf içeren ortalamalar LSD testine göre \%5'lik hata payı ile istatistiksel olarak birbirinden farklıdır

Billones-Baaijens ve ark., (2014) üç farklı Neofusicoccum türüne ( $N$. parvum, $N$. australe ve $N$. lutem) karşı farklı asma anaçları ve kalemlerini testlediği çalışmasında, türler arasındaki virülenslik farkına vurgu yapmışlar ve en saldırgan türün $N$. parvum olduğunu bildirmişlerdir. Bununla birlikte bu türlere karşı asma anaçlarındaki duyarlıı̆̆ın asma kalemleriyle kıyaslandığında, anaçların infeksiyonlara daha duyarlı oldukları bulunmuş, genetik farklılıkların bu olayda etkili olabileceğini ifade etmişlerdir. Çalışmamızda yer alan farklı çeşitlerin farklı genetik yapıda oldukları göz önüne alındığında, N. parvum izolatlarına gösterdikleri duyarlılık farklarının bu olayla ilişkili olabileceği düşünülmektedir. Asma gövde hastalıklarının bir başka patojeni Eutypa lata, taksonomik olarak Botryosphaeriaceae familyasından farklı olsa da bunların asma üzerindeki biyolojileri birbirine benzerdir. Cardot ve ark., (2019) Cabernet Sauvignon, Merlot ve Ugni Blanc şaraplık çeşitlerin Eutypa lata'ya karşı duyarlılıklarını test etmişler ve bunlardan Merlot'un en tolerant çeşit olduğunu bildirmişlerdir. Dayanıklılığın genetik ve biyokimyasal temelleri araştırıldığında Merlot çeşidinde hücresel olarak dayanıklılık mekanizmalarının diğer çeşitlere göre daha erken harekete geçtiği ve patojene karşı koymada daha başarılı olunduğu ortaya konmuştur. Merlot çeşidinde antifungal bileşiklerden osmotinler, ribonüklez benzeri proteinler ve hidrolitik özellikteki enzimlerin daha yüksek oranda sentezlendiği anlaşılmıştır.
Çalışmada kullanılan asma çeşitlerindeki gen ekspresyonlarının birbiriyle farklılıklar göstermiş olmasından dolayı, çeşitlerdeki duyarlılık farklarının ortaya çıktığı düşünülmektedir.

Ülkemizde ilk kez yürütülen bu tarzdaki bir çalışmanın daha da genişletilmesi, çok sayıda asma çeşidi ve anaçlarıyla daha büyük ölçekte yeniden ele alınması gerekmektedir. Ülkemiz birçok asma çeşidinin anavatanıdır ve asma gen kaynaklarının bu açıdan değerlendirilmesinin ülkemiz bağcılığına katkılar sağlayacağı düşünülmektedir.

\section{Teşekkür}

Bu çalışma Çukurova Üniv. BAP birimi tarafından FYL-2018-10608 nolu proje ile desteklenmiştir. Mali ve alt yapı katkılarından dolayı Ç.Ü. Rektörlüğüne ve Bitki Koruma Bölüm Başkanlığına teşekkür ederiz.

\section{Kaynaklar}

Akgül, D.S., Güngör-Savaş N., Teker T., Keykubat B., Mayorquin J.S. and Eskalen A. 2015. Fungal trunk pathogens of Sultana Seedless vineyards in Aegean Region of Turkey. Phytopathologia Mediterranea, 54 (2): 380-393.

Ayres, M., Sosnowski, M. and Wicks, T. 2011. A rapid technique for evaluating treatments for Eutypa dieback control. Wine \& Viticulture Journal, 26: 50-53.

Billones-Baaijens, R., Jones E.E., Ridgway H.J. and Jaspers, M.V. 2014. Susceptibility of common rootstock and scion varieties of 
grapevines to Botryosphaeriaceae species. Australasian Plant Pathology, 43: 25-31.

Cardot, C., Mappa, G., LaCamera, S., Gaillard, C., Vriet, C., Lecomte, P., Ferrari, G. and Coutos-Thevenot, P. 2019. Comparison of the molecular responses of tolerant, susceptible and highly susceptible grapevine cultivars during interaction with the pathogenic fungus Eutypa lata. Frontiers in Plant Science, 10 (991): 1-18.

Crous, P.W., Slippers, B., Wingfield, M.J., Rheeder, J., Marasas, W.F.O., Phillips, A.J.L., Alves, A., Burgess, T., Barber, P. and Groenewald, J.Z. 2006. Phylogenetic lineages in the Botryosphaeriaceae. Studies in Mycology, 55: 235-253.

Gomez, K.A. and Gomez, A.A. 1984. Statistical procedures for agricultural research. $2^{\text {nd }}$ ed. Wiley, New York, USA. 680p.

Kayım, M., Endes, A. ve Eskalen, A. 2015. First report of Neofusicoccum parvum and Diplodia seriata associated with wood canker and dieback on almond in Turkey. $18^{\text {th }}$ International Plant Protection Congress, 27-29 August 2015, Berlin Germany, (abstract) https://doi.org/10.13140/RG.2.1.3431.5 281.

Luque, J., Martos, S., Aroca, A., Raposo, R. and Garcia-Fihueres, F. 2009. Symptoms and fungi associated with declining mature grapevine plants in northeast Spain. Journal of Plant Pathology, 91: 381-390.

Ma, Y.P. and Dai, S.L. 2009. Extraction from Chrysantemum genome DNA high salt precipitation method CTAB. Biotechnology Bulletin, 7: 90-93.

Polat, Z., Akgül, D.S., Palacıoğlu, G. and Bayraktar, H. 2016. First report of Neofusicoccum parvum on kiwifruit in Turkey. International Agriculture
Congress Proceedings. 14-18 November 2016, Belgrade, Serbia. pp.15.

Slippers, B. and Wingfield, M.J. 2007. Botryosphaeriaceae as endophytes and latent pathogens of woody plants: diversity, ecology and impact. Fungal Biology Reviews, 21: 90-106.

Siebert, J. B. 2001. Eutypa: the economic toll on vineyards. Wines \& Vines, 4, 50-56.

Travadon, R., Rolshausen, P.E., Gubler, W.D., Cadle-Davidson, L. and Baumgartner, K. 2013. Susceptibility of cultivated and wild Vitis spp. to wood infection by fungal trunk pathogens. Plant Disease, 97: 1529-1536.

Úrbez-Torres, J.R., Leavitt, G.M., Voegel, T.M. and Gubler, W.D. 2006. Identification and distribution of Botryosphaeria spp. associated with grapevine cankers in California. Plant Disease, 90:1490-1503.

Úrbez-Torres, J.R. and Gubler, W.D. 2009. Pathogenicity of Botryosphaeriaceae species isolated from grapevine cankers in California. Plant Disease, 93: 584-592.

Úrbez-Torres, J.R. and Gubler, W.D. 2011. Susceptibility of grapevine pruning wounds to infection by Lasiodiplodia theobromae and Neofusicoccum parvum. Plant Pathology, 60: 261-270.

Úrbez-Torres, J.R., Phillips, A.J.L. and Gubler, W.D. 2015. Botryosphaeria dieback. Alınmıştır: Compendium of Grape Diseases, Second Edition. (ed), Wilcox, W.F., Gubler, W.D. and Uyemoto, J.K., APS Press. St. Paul Minnesota, USA, 3339.

White, T.J., Bruns, T.D., Lee, S.B. and Taylor, J. 1990. Amplification and direct sequencing of fungal ribosomal RNA genes for phylogenetics. Alınmıştır: PCR Protocols. (Eds MA Innis, D.H. Gelfand, J.J. Snisky, T.J White) pp. 315-322. (Academic Press: San Diego). 